GRAMMATICAL ERRORS IN DESCRIPTIVE TEXT WRITTEN BY DIFFERENT GRADES OF SMP DHARMA PANCASILA MEDAN

AN ARTICLE

Submitted in Partial Fulfilment of the Requirements for the Degree of Sarjana Pendidikan

By:

GRACE SEPRIMA PAKPAHAN

Registration Number: 2141121014

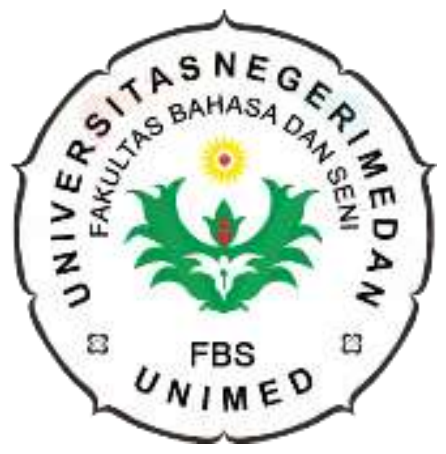

ENGLISH AND LITERATURE DEPARTMENT

FACULTY OF LANGUAGES AND ARTS

MEDAN STATE UNIVERSITY

2020 


\title{
ARTIKEL
}

\section{GRAMMATICAL ERRORS IN DESCRIPTIVE TEXT WRITTEN BY DIFFERENT GRADES OF SMP DHARMA PANCASILA}

\section{MEDAN}

\author{
Disusun dan Diajukan oleh: \\ Grace Seprima Pakpahan \\ NIM. 2141121014
}

Telah diverifikasi dan dinyatakan memenuhi syarat

Untuk diunggah pada jurnal online

Medan, Oktober 2020

\section{Menyetujui}

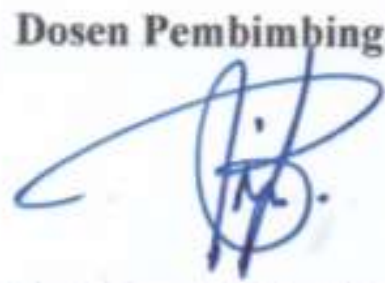

Prof. Dr. Berlin Sibarani, M.Pd. NIP. 195706151982031005

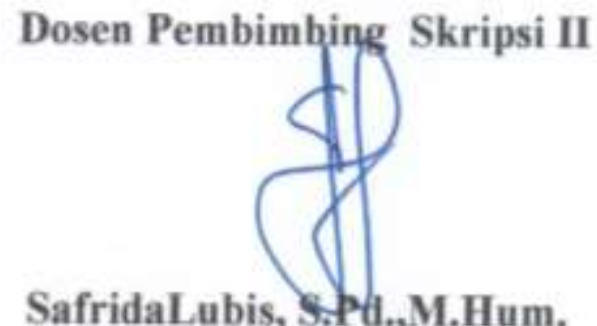

NIP. 197807212007012001

Piketahui oleh,

Ka. Program Studi Pendidikan Bahasa Inggris

NIP. 198005522008122003 


\author{
GRAMMATICAL ERRORS IN DESCRIPTIVE TEXT \\ WRITTEN BY DIFFERENT GRADES OF SMP DHARMA \\ PANCASILA MEDAN \\ *Grace Seprima Pakpahan \\ **Prof. Dr. Berlin Sibarani, M.Pd \\ ** Safrida Lubis, S.Pd, M.Hum
}

\begin{abstract}
The study aims to analyze grammatical errors in descriptive text written by different grades. This study was conducted by using descriptive qualitative design. The sources of this data are students in the eighth grade which consists of 21 students and the ninth grade which consists of 20 at SMP Dharma Pancasila Medan. The data of the study were obtained from students' descriptive text and interview. The analysis found that the grammatical errors written by eighth grade are subject verb agreement (46 cases), verb tense ( 7 cases), verb form (5 cases), singular/plural (2 cases), word form (11 cases) and sentence structure (26 cases), while the grammatical errors written by ninth grade are subject verb agreement (43 cases), verb tense ( 7 cases), verb form (4 cases), singular/plural (4 cases), word form (12 cases) and sentence structure (18 cases). From the analysis was found the factors underlying the grammatical error made by eighth grade are imperfect learning (4), overgeneralization (11) and influence of the native language (6), while the factors underlying the grammatical error made by ninth grade are imperfect learning (8), overgeneralization (6) and influence of the native language (6).
\end{abstract}

Key words : Grammatical errors, Descriptive text, Eighth and Ninth Grade Students

*Graduate Status

**Lecturer Status 


\section{INTRODUCTION}

\section{Background of the Study}

In learning English, there are four skills that must be mastered by students, those skills are listening and reading as the receptive skills and speaking and writing as productive skills.

One of the most important skills is writing. Harmer (2004) states that writing and speaking are totally different, in writing students have a lot of times to think about the ideas opposed to what they do in oral activities. Students can think what comes across their minds and consult to dictionaries and book references. But, to express the ideas in process of writing are the most difficult skill to be mastered by students.

Nunan (2003:88) states that writing is an intellectual activity of finding the ideas and thinking about the way to express and arrange them into a statement and paragraph that is clear to be understood by the people.

Based on the definition above, writing is a complex activity involving some stages of composition task completion. Everybody has to master the writing skill in daily life. It because that writing is also as a medium communication to show people what something do we want to say.

Writing is related to the genre of text. The students learn academic writing based on genres of text in the school. Genre is a place occasion, function, behavior and interaction structures (Knapp and Watkins, 2005: 82). Based on the function of the writing, writing can be distinguished in several kinds of genre. They divides genre of text into five main genres, they are genre of describing, explaining, instructing, arguing and narrating. In this study, the researcher just focuses in analyzing descriptive text.

Wishon and Burks (1980:128) say that in a descriptive writing a writer is required to give his/her readers a detailed vivid picture of a person, place, scene, object, or anything.

Furthermore, structure in descriptive text is the elements of a text are arranged to match its purpose. It is also called as text structure. Knapp and 
Watkins (2005: 101) explain that generic structure elements of descriptive text are classification (identification) and description.

In writing descriptive text, the students usually make some errors. The errors happen because of the students' ignorance of rules in writing.

Brown (2000) states that a "mistake" (in performance) refers to a performance error in that it is the learner's failure to utilize a known system correctly, while an "error" (in competence) is a noticeable deviation from the adult grammar of a native speaker, reflecting the inter-language competence of the learner.

Unfortunately, students often make some errors in writing a text. It could be happened because the students do not give their full attention to writing element. The element of writing is grammar.

Based on the problem that has found in the observation, the researcher is going to analyse the grammatical errors in descriptive text written by students. Finally, the researcher wrote this thesis which is related to Grammatical Errors in Descriptive Text Written by Different Grades of SMP Dharma Pancasila Medan.

\section{REVIEW OF LITERATURE}

\section{The Nature of Grammatical Error}

Corder (1973) states that grammatical error refers to the utterances which are either superficially deviant or inappropriate in terms of the target language grammar. Garner (2012) states that grammatical error is a term used in perspective grammar to describe an instance of faulty, unconventional or controversial usage, such as a misplaced modifier or an inappropriate verb tense.

\section{The Types of Grammatical Error}

Based on Linville (2004:86), there are six types of grammatical error in English; (1) subject-verb agreement, (2) Verb tense, (3) verb form, (4) singular/plural noun endings, (5) word form, (6) sentence structure.

\section{Factors Underlying the Grammatical Error}


Cowan (2008) states that the grammatical errors made by second language learner divided into three factors; (1) imperfect learning, (2) overgeneralization, (3) influence of native language.

\section{The Nature of Descriptive Text}

Knapp and Watkins (2005:98) state that descriptive is one of the fundamental functions of any language system and one of the first skill emergent language-users learn to control.

\section{The Text Structure of Descriptive Text}

Knapp and Watkins (2005: 101) explain that generic structure elements of descriptive text are classification (identification) and description.

\section{RESEARCH METHODOLOGY}

\section{Research Design}

This study has been conducted by using descriptive qualitative design. In this study, it has been analyzed the grammatical errors in descriptive text written by different grades.

\section{Data and Source of Data}

The data needed to answer the research problem is the students' descriptive text. The sources of this data are the grade VIII which is consisted of 21 students and grade IX which is consisted of 20 students of SMP Dharma Pancasila Medan.

\section{Technique of Data Collection}

The data collection in this study will be collected from writing test that is as documentation to collect the data of grammatical errors types in students' writing text. In collecting the data, the researcher interviewed the students to collect the data of the factors underlying the grammatical error.

\section{The Technique of Data Collection}

In this study, there are some steps in analyzing data. They are: 
1. Identifying types of grammatical errors based on Linville (2004:86).

2. Classifying types of grammatical errors: subject verb agreement, verb tense, verb form, singular and plural noun, word form, sentence structure.

3. Determining the factors underlying the grammatical error.

4. Concluding and giving suggestions based on the data of analysis.

\section{DATA ANALYSIS}

\section{Types of grammatical errors}

The 21 descriptive texts as sources of the study is written by VIII-C and the 20 descriptive texts as sources of the study is written by IX-A at SMP Dharma Pancasila Medan, in which they is given the same topic about describing people. The data is identified and classified into six types of grammatical errors: subject verb agreement, verb tense, verb form, singular/plural noun endings, words form and sentence structure.

The Data Analysis of Grammatical Errors in Descriptive Text Written by Eighth Grade

\begin{tabular}{|c|l|l|c|}
\hline No. & \multicolumn{1}{|c|}{ Grammatical Error } & \multicolumn{1}{|c|}{ Data } & $\begin{array}{c}\text { Number of } \\
\text { grammatical } \\
\text { error }\end{array}$ \\
\hline 1. & Subject Verb Agreement & He have nose sharp. & 46 \\
\hline 2. & Verb Tense & He always come let to school. & 7 \\
\hline 3. & Verb Form & $\begin{array}{l}\text { His hobby is playing football } \\
\text { and dance. }\end{array}$ & 5 \\
\hline 4. & Singular/Plural & He is my boy friends. & 2 \\
\hline 5. & Word form & He is kind and entertaining. & 11 \\
\hline 6. & Sentence Structure & $\begin{array}{l}\text { She is always make me smile } \\
\text { everyday. }\end{array}$ & 26 \\
\hline
\end{tabular}

The Data Analysis of Grammatical Errors in Descriptive Text Written by Ninth Grade

\begin{tabular}{|c|l|l|c|}
\hline No. & \multicolumn{1}{|c|}{ Grammatical Error } & \multicolumn{1}{|c|}{ Data } & $\begin{array}{c}\text { Number of } \\
\text { grammatical } \\
\text { error }\end{array}$ \\
\hline 1. & Subject Verb Agreement & $\begin{array}{l}\text { He live at Jl. Flamboyan raya } \\
\text { musyawarah. }\end{array}$ & 43 \\
\hline 2. & Verb Tense & $\begin{array}{l}\text { She always asked me about } \\
\text { homework. }\end{array}$ & 7 \\
\hline
\end{tabular}




\begin{tabular}{|c|l|l|c|}
\hline 3. & Verb Form & $\begin{array}{l}\text { He also likes dance and V is a } \\
\text { crazy boy. }\end{array}$ & 4 \\
\hline 4. & Singular/Plural & She has 4 childreens. & 4 \\
\hline 5. & Word form & He likes read and orange color. & 12 \\
\hline 6. & Sentence Structure & He already finishe from SMA. & 18 \\
\hline
\end{tabular}

\section{Factors Underlying the Grammatical Error}

Based on Cowan (2008) there are some factors underlying the grammatical errors, they are imperfect learning, overgeneralization and influence of the native language. Based on the analyzed data, the result could be seen in the following description.

The Data Analysis Factors Underlying the Grammatical Error in Descriptive Text Written by Eighth Grade

\begin{tabular}{|c|l|c|}
\hline No. & Factors Underlying the Grammatical Error & $\begin{array}{c}\text { Number of factors underlying } \\
\text { the grammatical error }\end{array}$ \\
\hline 1. & Imperfect learning & 4 \\
\hline 2. & Overgeneralization & 6 \\
\hline 3. & Influence of the native language & \\
\hline
\end{tabular}

The Data Analysis Factors Underlying the of Grammatical Error in Descriptive Text Written by Ninth Grade

\begin{tabular}{|c|l|c|}
\hline No. & Factors Underlying the Grammatical Error & $\begin{array}{c}\text { Number of factors underlying } \\
\text { the grammatical error }\end{array}$ \\
\hline 1. & Imperfect learning & 8 \\
\hline 2. & Overgeneralization & 6 \\
\hline 3. & influence of the native language & 6 \\
\hline
\end{tabular}




\section{Research Finding}

The researcher finds the results of this study. It could be seen below:

a. From the data analysis the researcher found that types of grammatical errors in descriptive text written by eighth grade students are subject verb agreement with 46 cases, verb tense with 7 cases, verb form with 5 cases, word form with 12 cases, singular/plural ending noun with 2 cases, sentence structure with 25 cases while types of grammatical errors in descriptive text written by ninth grade students are subject verb agreement with 43 cases, verb tense with 7 cases., verb form with 4 cases, word form with 12 cases, singular/plural ending noun with 4 cases, sentence structure with 26 cases.

b. From the data analysis the researcher found that factors underlying of grammatical errors in descriptive text written by eighth grade students are imperfect learning with number of error is 4, overgeneralization with number of error is 11 , and influence of native language with number of error is 6, while the factors underlying of grammatical errors in descriptive text written by ninth grade students are imperfect learning with number of error is 8 , overgeneralization with number of error is 6 , and influence of native language with number of error is 6 .

\section{CONCLUSION AND SUGGESTIONS}

\section{Conclusion}

The analysis of grammatical errors in descriptive text has different total number that is written by different grades. Based on the total number, the researcher concludes that the students of ninth grade are more capable in writing descriptive text with the correct sentence patterns. And The main factor of grammatical error written by eighth grade is caused by overgeneralization and imperfect learning is the main factor of ninth grade.

\section{Suggestion}

1. The teacher should pay attention and give proper correction to the students' writing by using appropriate error strategies. The researcher 
demanded that the teachers provided the methods in learning and teaching process.

2. The researcher suggests that the students can improve their writing skill. Students also must be aware to learn their grammatical errors to avoid in repeating the same errors.

3. Other researcher should conduct further studies on grammatical features of every genre of text involve a wider circle of participants from grade and level.

\section{REFERENCES}

Ary, D. et al. 2010. Introduction to Research in Education English Edition. Canada: Wasworth Cengage Learning.

Brown, Douglas, 2000. Principles of Language Learning and Teaching. New York : Pearson Education, Inc.

Azar, Betty Schramper, 1998. Understanding and Using English Grammar. Upper Sadlle River: Prentice Hall Regents.

Bogdan, R.C and Biklen, SK.2007. Qualitative Research for Education: An Introduction to Theory and Methods. Needham Heights, MA: Allyn and Bacon.

Cowan, Ron (2008). The Teacher's Grammar of English. USA: Cambridge University Press.

Duff, P.A. 2008. Case Study Research in Applied Linguistics. USA: Taylor \& Francis Group.

Farooq, Muhammad J and Ashraf, Muhammad K (2011). Cognitive Development in Jean Piaget's Work and its Implications for Teachers. Vol.12(8).World Applied Sciences Journal.

Garner, B. A. (2012). Which language rules to flout. Or flaunt?. The New York Times, New York.

Harmer, J. 2004. How to Teach Writing. Harlow: Pearson Education Ltd.

Hernandez, M. S. (2011). Raising students awareness about grammatical and lexical errors via email. Revista de Lenguas Modernas,4, 263-281. 
Kaur, Quistina and Thilaga (2017). Grammar Errors Made by ESL Tertiary Students in Writing. Vol.10 (5). English Language Teaching.

Knapp, Peter and Watkins, Megan. 2005. Genre, Text, Grammar: Technologies for Teaching and Assessing Writing. Australia: University of New South Wales Press, Ltd.

Kvale, D. 1996. Interviews. London: SAGE Publication.

Mabuan, R.A. 2015. An Analysis of Weblogs' Grammatical Errors of Filipino Learners of English as Second Language. Vol 03. DLSU Research Cogress. 